\title{
ITP2 IPS \\ IMPLEMENTASI PENDIDIKAN MULTIKURTURAL MELALUI PENDEKATAN NILAI LUHUR BUDAYA DAN PANCASILA UNTUK MEMBANGUN KARAKTER MAHASISWA DALAM MEGHADAPI ARUS GLOBALISASI
}

\author{
Muhammad Misbahudholam A.R. ${ }^{1}$
}

\begin{abstract}
Abstrak
Arus globalisasi memang sangat kuat terasa disetiap sendi-sendi kehidupan bermasyarakat, berbangsa dan bernegara. Sendi-sendi tersebut yaitu ediologi, politik ekonomi, sosial budaya, pertahanan dan keamanan. Lunturnya nilai-nilai nasionalisme dan solidaritas adalah salah satu penyakit yang sedang diderita anak negeri ini. Faktor ini pula yang melatar belakangi munculnya kepedulian terhadap pentingnya implementasi pendidikan multikurtural dalam membangun karakter/budi pekerti yang baik. Karakter bangsa yang berbasis pada multikultural sesuai dengan semboyan "Bhinneka tunggal ika" harus menjadi pondasi dalam pembangunan karakter/budi pekerti masa depan bangsa dan negara Indonesia. Tujuan dalam penelitian ini adalah: (1) mengetahui bagaimana implementasi pendidikan multikultural memalui pendekatan nilai luhur budaya dan pancasila untuk membangun karakter mahasiswa dalam meghadapi arus globalisasi di STKIP PGRI Sumenep; (2) mengetahui faktor-faktor pendukung dan penghambat dalam mengimplementasikan pendidikan multikultural memalui pendekatan nilai luhur budaya dan pancasila di STKIP PGRI Sumenep. Penelitian ini merupakan penelitian studi kasus dengan subjek penelitian STKIP PGRI Sumenep yang meliputi, ketua, dosen, dan mahasiswa. Pendekatan yang digunakan adalah pendekatan kualitatif dengan metode analisis deskriptif. Adapun hasil penelitian ini adalah: (1) dalam mengimplementasikan pendidikan multikultural melalui pendekatan nilai luhur budaya dan pancasila berjalan dengan sangat dan mampu membangun karakter mahasiswa STKIP PGRI Sumenep (2) faktor pendukunggnya adalah adanya kerjasama yang baik antara semua komponen di STKIP PGRI Sumenep, mulai dari ketua, dosen, mahasiswa dan orang tua mahasiswa. Adanya keluasan kepada mahasiswa dalam mengembangkan potensinya baik melalui intra maupun ekstra sekolah.
\end{abstract}

Katakunci: Pendidikan Multikultural, Karakter Mahasiswa.

\begin{abstract}
Globalization is indeed very strongly felt in every aspects of life of society, nation and state. The joints are ediologi, political, economic, social, cultural, defense and security. The fade of nationalism and solidarity is one of the diseases that are suffered by children of this country. This factor is also the background for the emergence of awareness of the importance of education implementation multikurtural in building character/good manners. Characters based on a multicultural nation in accordance with the motto "Bhineka Tunggal Ika/Unity in Diversity" should be the foundation in the development of the character / character the future of the nation of Indonesia. The purpose of this research are: (1) knowing how to approach memalui implementation of multicultural education and cultural values of Pancasila to build student character in meghadapi globalization in STKIP PGRI Sumenep; (2) determine the factors supporting and implementing multicultural education memalui approach and the cultural values of Pancasila in STKIP PGRI Sumenep. This research is a case study with research subjects covering STKIP PGRI Sumenep, chairman, faculty, and students. The approach used is a qualitative approach with descriptive analysis method. The results of this study are: (1) to implement multicultural education through the approach of cultural values and Pancasila run very and able to build student character STKIP PGRI Sumenep (2) factors pendukunggnya is good cooperation between all the components in STKIP PGRI Sumenep, starting from the chairman, lecturers, students and parents of students. Their breadth to students in developing their potential through both intra and extra school.
\end{abstract}

Keywords: Multicultural Education, Student Character.

\footnotetext{
${ }^{1}$ STKIP PGRI Sumenep_misbahudholam.ar@gmail.com
} 


\section{Pendahuluan}

Arus globalisasi memang sangat kuat terasa disetiap sendi-sendi kehidupan bermasyarakat, berbangsa dan bernegara. Sendi-sendi tersebut yaitu ediologi, politik ekonomi, sosial budaya, dan pertahanan dan keamanan. Semua sendisendi kehidupan bermasyarakat, berbangsa dan bernegara terasa sakit oleh dahsyatnya pengaruh arus globalisasi. Lunturnya nilai-nilai nasionalisme dan solidaritas adalah salah satu penyakit yang sedang diderita anak negeri ini. Faktor ini pula yang melatar belakangi munculnya kepedulian terhadap pentingnya implementasi pendidikan multikurtural dalam membangun karakter/budi pekerti yang baik. Karakter bangsa yang berbasis pada multikultural sesuai dengan semboyan "Bhenneka tunggal ika" harus menjadi pondasi dalam pembangunan karakter/budi pekerti masa depan bangsa dan negara Indonesia. Apabila diperhatikan dari negaranegara yang sudah maju, maka yang menonjol adalah kuatnya karakter yang mereka miliki. Tujuan utama penerapan pendidikan multikultural di tingkat nasional hendaknya dititikberatkan pada pemahaman dan penghargaan mahasiswa terhadap budayanya sendiri dan budaya orang lain, mencakup agama, berlandaskan semboyan bhinneka tunggal ika serta Pancasila. Untuk itu maka diperlukan adanya penataan ulang dan penguatan pendidikan kewarganegaraan (PKn), IPS, dan pendidikan agama dengan memasukkan muatan materi keanekaragaman nilai-budaya, didukung oleh penelitian sosiologis dan antropologis untuk pendidikan.

Multikulturalitas bangsa Indonesia ini bisa diibaratkan pisau bermata ganda. Di satu sisi ia menjadi potensi yang berharga dalm membangun peradaban bangsa,disisi lain apabila tidak dapat dikelola dengan baik, multikulturalitas tersebut akan memunculkan konflik yang mampu menghancurkan sendi-sendi kehidupan berbangsa dan bernegara bahkan disintegrasi bangsa. Perbedaan-perbedaan tersebut akan menjadi beban atau kekayaan tergantung bagaimana cara mengolahnya. Dengan semboyan Bhineka Tunggal Ika yang telah dicetuskan oleh para founding fathers bangsa ini, diharapkan masyarakat Indonesia dapat hidup bersama berdampingan dalam suasana aman, damai, dan sejahtera.

Multikulturalisme sebenarnya merupakan konsep di mana sebuah komunitas dalam konteks kebangsaan dapat mengakui keberagaman, perbedaan, dan kemajemukan budaya, baik ras, suku, etnis, dan agama. Sebuah konsep yang memberikan pemahaman kita bahwa sebuah bangsa yang plural atau majemuk adalah bangsa yang dipenuhi dengan budaya- budaya yang beragam (multikultur). Bangsa yang multikultur adalah bangsa yang kelompok kelompok etnik atau budaya (etnic an cultural groups) yang ada dapat hidup berdampingan dengan damai dalam prinsip (co-existence) yang ditandai oleh kesediaan untuk menghormati budaya lain (Nanih 2001 : 34). Adanya keanekaragaman tersebut tidak hanya memberikan keunikan yang menarik dan unik. Namun dilain sisi justru menjadi pemicu munculnya berbagai konflik.

Istilah pendidikan multikultural dapat digunakan, baik pada tingkat deskriptif dan normatif yang menggambarkan isu-isu dan masalah-masalah pendidikan yang berkaitan dengan masyarakat multikultural. Lebih jauh juga mencakup pengertian tentang pertimbangan terhadap kebijakan-kebijakan dan strategistrategi pendidikan dalam masyarakat multikultural. Dalam konteks deskriptif, maka pendidikan multikultural seyogyanya berisikan tentang tema-tema mengenai toleransi, perbedaan ethno-cultural dan agama, bahaya diskriminasi, penyelesaian konflik dan mediasi, hak asasi manusia, demokratisasi, pluralis, kemanusiaan universal, dan subjek-subjek lain yang relevan (Muhaemin $2004:$ 4). Sejalan dengan itu, Tilaar ( 2002 : 5) mengemukakan bahwa pendidikan multikultural merupakan proses penanaman cara hidup menghormati, tulus dan toleran terhadap keragaman budaya yang hidup di tengah-tengah masyarakat plural.

Pendidikan multikultural bertujuan untuk mengembangkan potensi yang dimiliki oleh peserta didik dan juga menciptakan keharmonisan dalam perbedaan. Bahwasanya manusia diciptakan oleh Tuhan masing-masing memiliki kelebihan dan kekurangan. Kendatipun demikian, adalah kewajiban manusia untuk mengembangkan apa yang telah diberikan Tuhan dan dalam hal ini lingkungan juga sangat berperan penting dalam membantu mengembangkan segala potensi individu maupun sosial. Sehingga gagasan pendidikan multikultural merupakan salah satu contoh bahwa lingkungan sangat berperan dalam pengembangan potensi manusia. 
Perguruan tinggi memegang peranan penting dalam menanamkan nilai multikultural pada siswa. Bila mereka memiliki nilai-nilai kebersamaan, toleran, cinta damai, dan menghargai perbedaan, maka nilai-nilai tersebut akan tercermin pada tingkah laku mereka sehari-hari karena terbentuk pada kepribadiannya. Bila hal tersebut berhasil dimiliki para generasi muda kita, maka kehidupan mendatang dapat diprediksi akan relatif damai dan penuh penghargaan antara sesama dapat terwujud. Oleh karena itu, kepedulian sekolah dalam hal ini guru tidak hanya dituntut secara professional mengimplementasikan nilai-nilai multikultural dalam berbagai kesempatan yang ada di sekolah dalam setiap mata pelajaran, tetapi mereka juga dituntut untuk mampu menanamkan nilai-nilai keberagamaan yang inklusif kepada para siswa.

Pembahasan implementasi pendidikan multikurtural memalui pendekatan nilai luhur budaya dan pancasila untuk membangun karakter mahasiswa dalam meghadapi arus globalisasi menjadi penting, mengingat pembahasan yang sifatnya operasional dan implementasinya yang masih langka. Dalam tulisan ini mencoba mengkaji implementasi pendidikan multikultural secara praktis di STKIP PGRI Sumenep. Adapun tujuan dalam tulisan ini antara lain: bagaimana kajian tentang pendidikan multikultural, bagaimana pendidikan berbasis multikultural, bagaimana implementasi pendidikan multikurtural memalui pendekatan nilai luhur budaya dan pancasila untuk membangun karakter mahasiswa dalam meghadapi arus globalisasi dan untuk mengetahui faktor-faktor pendukung dan penghambat dalam mengimplementasikan pendidikan multikultural memalui pendekatan nilai luhur budaya dan pancasila di STKIP PGRI Sumenep.

\section{Metode penelitian}

Penelitian tentang implementasi pendidikan multikurtural memalui pendekatan nilai luhur budaya dan pancasila untuk membangun Karakter mahasiswa dalam meghadapi arus globalisasi, ini, termasuk dalam kategori penelitian lapangan (field research). Jenis penelitian lapangan adalah penelitian yang dilakukan secara intensif, terperinci, dan mendalam terhadap suatu objek tertentu dengan mempelajarinya sebagai suatu kasus. Penelitian yang pengumpulan datanya dilakukan di lapangan, seperti di lingkungan masyarakat dan pen- didikan, merupakan jenis penelitian kualitatif yang bersifat deskriptik analitik. Yakni menggambarkan dan menyajikan fakta-fakta secara sistematis tentang keadaan objek yang sebenarnya.

Pendekatan yang dilakukan dalam penelitian ini adalah fenomenologi. Pendekatan fenomenologi secara konseptual adalah sebuah studi tentang penampakan sebuah objek, peristiwa, atau kondisi dalam persepsi individu. Pendekatan ini digunakan untuk melacak atau mengetauhi keberagaman yang terdapat di STKIP PGRI Sumenep.

Metode penentuan subjek sering disebut sebagai metode penentuan sumber data. Maksud dari sumber data penelitian adalah subjek dari mana data itu di peroleh. Adapun yang menjadi sumber data atau informan utama dalam penelitian ini adalah Ketua STKIP PGRI Sumenep dan Dosen STKIP PGRI Sumenep, serta mahasiswa STKIP PGRI Sumenep.

Metode pengumpulan data adalah cara yang ditempuh peneliti untuk mendapatkan data dan fakta-fakta yang ada pada subjek maupun objek penelitian. Untuk memperoleh data yang valid, penulis mengunakan teknik pengumpulan data sebagai berikut: (1) Wawancara, adalah bentuk komunikasi antara dua orang, melibatkan seseorang yang ingin memperoleh informasi dari seorang lainnya dengan mengajukan pertanyaanpertanyaan tujuan tertentu. Interview dipakai untuk memperoleh informasi atau data yang dibutuhkan dalam penelitian. Semisal peristiwa yang sudah lewat, argumen, atau pendapat yang mana hal tersebut masih terkait dengan penelitian ini. (2) Observasi, pengamatan merupakan suatu teknik atau cara pengumpulan data dengan jalan mengadakan pengamatan terhadap kegiatan yang sedang berlangsung. Selain itu juga untuk memperoleh data-data yang terkait dengan implementasi pendidikan multikultural secara praktis di STKIP PGRI Sumenep. (3) Dokumentasi, merupakan catatan peristiwa yang sudah berlalu. Dokumen ini bisa berbentuk tulisan, gambar, atau karya-karya

Analisis data adalah proses mencari dan menyusun secara sistematis data yang diperoleh dari hasil wawancara, cacatan lapangan dan bahan-bahan lain, sehingga dapat mudah dipahami, dan semuanya dapat diinformasikan kepada orang lain.Penelitian peneliti menggunakan satu metode yaitu metode teknik analisis induktif. Teknik analisis data Induktif 
adalah proses logika yang berangkat dari data empirik lewat observasi menuju ke suatu teori, atau mengorganisasi fakta-fakta atau data-data yang terpisah-pisah menjadi suatu rangkaian saling berhubungan.

\section{Pembahasan}

Menurut bahasa, karakter adalah tabiat atau kebiasaan. Sedangkan menurut ahli psikologi, karakter adalah sebuah sistem keyakinan dan kebiasaan yang mengarahkan tindakan seorang individu. Karena itu, jika pengetahuan mengenai karakter seseorang itu dapat diketahui, maka dapat diketahui pula bagaimana individu tersebut akan bersikap untuk kondisi-kondisi tertentu.

Dilihat dari sudut pengertian, ternyata karakter dan akhlak tidak memiliki perbedaan yang signifikan. Keduanya didefinisikan sebagai suatu tindakan yang terjadi tanpa ada lagi pemikiran lagi karena sudah tertanam dalam pikiran, dan dengan kata lain, keduanya dapat disebut dengan kebiasaan.

\section{A. Mekanisme Pembentukan Karakter}

Unsur terpenting dalam pembentukan karakter adalah pikiran karena pikiran, yang di dalamnya terdapat seluruh program yang terbentuk dari pengalaman hidupnya, merupakan pelopor segalanya. Program ini kemudian membentuk sistem kepercayaan yang akhirnya dapat membentuk pola berpikirnya yang bisa mempengaruhi perilakunya. Jika program yang tertanam tersebut sesuai dengan prinsip-prinsip kebenaran universal, maka perilakunya berjalan selaras dengan hukum alam. Hasilnya, perilaku tersebut membawa ketenangan dan kebahagiaan. Sebaliknya, jika program tersebut tidak sesuai dengan prinsip-prinsip hukum universal, maka perilakunya membawa kerusakan dan menghasilkan penderitaan. Oleh karena itu, pikiran harus mendapatkan perhatian serius.

Tentang pikiran, Joseph Murphy mengatakan bahwa di dalam diri manusia terdapat satu pikiran yang memiliki ciri yang berbeda. Untuk membedakan ciri tersebut, maka istilahnya dinamakan dengan pikiran sadar (conscious mind) atau pikiran objektif dan pikiran bawah sadar (subconscious mind) atau pikiran subjektif. Penjelasan Adi W. Gunawan mengenai fungsi dari pikiran sadar dan bawah sadar menarik untuk dikutip.
Pikiran sadar yang secara fisik terletak di bagian korteks otak bersifat logis dan analisis dengan memiliki pengaruh sebesar $12 \%$ dari kemampuan otak. Sedangkan pikiran bawah sadar secara fisik terletak di medulla oblongata yang sudah terbentuk ketika masih di dalam kandungan. Karena itu, ketika bayi yang dilahirkan menangis, bayi tersebut akan tenang di dekapan ibunya karena dia sudah merasa tidak asing lagi dengan detak jantung ibunya. Pikiran bawah sadar bersifat netral dan sugestif.

Untuk memahami cara kerja pikiran, kita perlu tahu bahwa pikiran sadar (conscious) adalah pikiran objektif yang berhubungan dengan objek luar dengan menggunakan panca indra sebagai media dan sifat pikiran sadar ini adalah menalar. Sedangkan pikiran bawah sadar (subsconscious) adalah pikiran subjektif yang berisi emosi serta memori, bersifat irasional, tidak menalar, dan tidak dapat membantah. Kerja pikiran bawah sadar menjadi sangat optimal ketika kerja pikiran sadar semakin minimal.

Pikiran sadar dan bawah sadar terus berinteraksi. Pikiran bawah sadar akan menjalankan apa yang telah dikesankan kepadanya melalui sistem kepercayaan yang lahir dari hasil kesimpulan nalar dari pikiran sadar terhadap objek luar yang diamatinya. Karena, pikiran bawah sadar akan terus mengikuti kesan dari pikiran sadar, maka pikiran sadar diibaratkan seperti nahkoda sedangkan pikiran bawah sadar diibaratkan seperti awak kapal yang siap menjalankan perintah, terlepas perintah itu benar atau salah. Di sini, pikiran sadar bisa berperan sebagai penjaga untuk melindungi pikiran bawah sadar dari pengaruh objek luar.

Karakter terbentuk dari hasil internalisasi berbagai kebajikan (virtues) yang diyakini dan digunakan sebagai landasan untuk cara pandang, berpikir, bersikap, dan bertindak. Kebajikan terdiri atas sejumlah nilai, moral, dan norma, seperti jujur, berani bertindak, dapat dipercaya, dan hormat kepada orang lain. Interaksi seseorang dengan orang lain menumbuhkan karakter masyarakat dan karakter bangsa.

V. Campbell dan R. Obligasi (1982) menyatakan ada beberapa faktor yang berpengaruh dalam pembentukan karakter seseorang: (1) Faktor keturunan, (2) Pengalaman masa kanak-kanak, (3) Pemodelan oleh orang dewasa atau orang yang lebih tua, (4) Pengaruh lingkungan sebaya, (5) Lingkungan fisik dan 
sosial, (6) Subtansi materi di sekolah atau lembaga pendidikan lain, (7) Media massa.

Untuk mengembangkan karakter yang baik perlu ada suatu penentuan dan pendefinisian kualitas karakter yang akan ditanamkan sehingga dapat dimengerti oleh semua orang antara lain dengan memberikan ilustrasi-ilustrasi atau aktivitas.

Dalam proses pembentukan karakter yang baik perlu adanya kontrol internal dan kontrol sosial yang menuntut individu untuk memiliki karakter positif tertentu. Misalnya saja sebagai pendidik (dosen) dalam suatu komunitas pendidikan, dibutuhkan karakter seperti jujur, perhatian, sabar, dan karakter positif lain sebab pendidik dalam komunitas pendidikan berperan sebagai teladan dan model bagi anak didiknya.

\section{B. Pendidikan Multikultural}

Pendidikan multikultural pada hakikatnya adalah merupakan suatu sikap dalam memandang keunikan manusia dengan tanpa membedakan ras, budaya, jenis kelamin, seks, kondisi jasmaniah atau status ekonomi seseorang (Skeel, 1995). Pendidikan multikultural (multikultural education) merupakan strategi pendidikan yang memanfaatkan keberagaman latar belakang kebudayaan dari para peserta didik sebagai salah satu kekuatan untuk membentuk sikap multikultural. Strategi ini sangat bermanfaat, sekurang-kurangnya bagi sekolah sebagai lembaga pendidikan dapat membentuk pemahaman bersama atas konsep kebudayaan, perbedaan budaya, keseimbangan, dan demokrasi dalam arti yang luas (Liliweri : 2005).

Pembelajaran pendidikan multikultural didasarkan pada gagasan filosofis tentang kebebasan, keadilan, kesederajatan dan perlindungan terhadap hak-hak manusia. Hakikat pendidikan multikultural mempersiapkan seluruh siswa untuk bekerja secara aktif menuju kesamaan struktur dalam organisasi dan lembaga sekolah. Pendidikan multikultural bukanlah kebijakan yang mengarah pada pelembagaan pendidikan dan pengajaran inklusif dan pengajaran oleh propaganda pluralisme lewat kurikulum yang berperan bagi kompetisi budaya individual. Pembelajaran pendidikan multikultural berusaha memberdayakan siswa untuk mengembangkan rasa hormat kepada orang yang berbeda budaya, memberi kesempatan untuk bekerja bersama dengan orang atau kelompok orang yang berbeda etnis atau rasnya secara langsung. Pendidikan multikultural juga membantu siswa untuk mengakui ketepatan dari pandangan-pandangan budaya yang beragam, membantu siswa dalam mengembangkan kebanggaan terhadap warisan budaya mereka, menyadarkan siswa bahwa konflik nilai sering menjadi penyebab konflik antar kelompok masyarakat (Savage \& Armstrong, 1996). Pendidikan multikultural diselenggarakan dalam upaya mengembangkan kemampuan siswa dalam memandang kehidupan dari berbagai perspektif budaya yang berbeda dengan budaya yang mereka miliki, dan bersikap positif terhadap perbedaan budaya, ras, dan etnis. (Farris \& Cooper, 1994).

Sebagai Sebuah wacana baru, pengertian pendidikan multikultural menurut pendapat Andersen dan Cusher (1994:320) bahwa pendidikan multikultural dapat diartikan sebagai pendidikan mengenal keragaman kebudayaan. James Banks (1993:3) mendefinisikan pendidikan multikultural sebagai pendidikan untuk people of color. Artinya, pendidikan multikultural ingin mengeksplorasi perbedaan sebagai keniscayaan. Kemudian, bagaimana kita mampu menyikapi perbedaan tersebut dengan penuh toleran dan semangat egaliter. James A Banks (1993) berpendapat pendidikan multikultural adalah konsep, idea atau falsafah sebagai suatu kepercayaan (set of believe) dan penjelasan yang mengakui dan menilai pentingnya keragaman budaya dan etnis di dalam membentuk gaya hidup pengalaman sosial, identitas pribadi, kesempatan pendidikan dari individu, kelompok maupun Negara. Hilda Hernandez dalam bukunya Multikultural Education: A Teacher Guide to Linking Content, mengartikan pendidikan multikultural sebagai prespektif yang mengakui realitas politik, sosial, dan ekonomi, yang dialami oleh masing-masing individu dalam pertemuan yang kompleks dan beragam secara kultur, dan merefleksikan pentingnya budaya, ras seksualitas dan gender ,etnisitas, agama, status sosial, ekonomi, dan pengecualian pengecualian dalam proses pendidikan . sebagai media transformasi ilmu pengetahuan(transfer of knowledge) hendaknya mampu memberikan nilai nilai multikulturalisme dengan saling menghargai dan menghormati atas realitas yang beragam (plural), baik latar belakang maupun basis sosio budaya yang melingkupinya. 
Pendidikan multikultural (multikultural Education) merupakan respon terhadap perkembangan keragaman populasi sekolah, sebagaimana tuntutan persamaan hak bagi setiap kelompok. Dalam dimensi lain, pendidikan multikultural merupakan pengembangan kurikulum dan aktifitas pendidikan untuk memasuki berbagai pandangan ,sejarah, prestasi siswa. Melalui pembelajaran multikultural, subyek belajar dapat mencapai kesuksesan dalam mengurangi prasangka dan diskriminasi (Banks, 1993). Dengan kata lain, variabel sekolah terbentuk di mana besar kelompok rasial dan etnis yang memiliki pengalaman dan hak yang sama dalam proses pendidikan. Pelajar mampu mengembangkan keterampilannya dalam memutuskan sesuatu secara bijak. Mereka lebih menjadi suatu subyek dari pada menjadi obyek dalam suatu kurikulum. Mereka menjadi individu yang mampu mengatur dirinya sendiri dan merefleksi kehidupan untuk bertindak secara aktif. Mereka membuat keputusan dan melakukan sesuatu yang ber hubungan dengan konsep, pokok-pokok masalah yang mereka pelajari. Mereka mengembangkan visi sosial yang lebih baik dan memperoleh ilmu pengetahuan dan mengetahui bagaimana berperilaku terhadap para pelajar yang bermacam-macam kulturnya di dalam kelas. Mereka mengetahui perbedaan-perbedaan nilai-nilai dan kultur dan bentuk-bentuk perilaku yang beraneka ragam.

\section{Pendekatan Pendidikan Multikultural.}

Untuk mendesain pendidikan multikultural dalam tatanan masyarakat yang kompleks dan penuh antar kelompok, budaya, suku dan lain sebagainya ada beberapa pendekatan dalam proses pendidikan multikultural (Mahfud:2009) yaitu: Pertama, tidak menyamakan pandangan pendidikan (education) dengan persekolahan (schooling), atau pendidikan multikultural dengan program program sekolah formal. Pandangan yang lebih luas mengenai pendidikan sebagai transmisi kebudayaan membebaskan pendidik dari asumsi keliru bahwa tanggung jawab primer mengembangkan kompetensi kebudayaan di kalangan anak didik semata-mata berada di tangan mereka: Tapi justru semakin banyak pihak yang bertanggung jawab karena program-program sekolah seharusnya terkait dengan pembelajaran di sekolah. Kedua, menghindari pandangan yang menyamakan kebudayaan kelompok etnik, artinya tidak perlu lagi mengasosiasikan kebudayaan semata-mata dengan kelompok etnik sebagaimana yang terjadi selama ini secara tradisional para pendidik lebih mengasosiasikan kebudayaan dengan kelompok yang relatif self sufficient, ketimbang dengan sejumlah orang yang secara terus menerus dan berulang-ulang terlibat satu sama lain terlibat dalam satu kegiatan. Dalam konteks pendidikan multikultural, pendekatan ini diharapkan dapat mengilhami para penyusun pendidikan multikultural untuk melenyapkan kecenderungan memandang anak didik secara stereotipe menurut identitas etik mereka: sebaliknya mereka akan meningkatkan eksplorasi pemahaman yang lebih besar, mengenai kesamaan perbedaan di kalangan anak didik dari berbagai kelompok etnik.

Ketiga, karena pengembangan kompetensi dalam suatu kebudayaan baru biasanya membutuhkan interaksi inisiatif dengan orangorang yang sudah memiliki kompetensi maka dapat dilihat lebih jelas bahwa upaya untuk mendukung sekolah-sekolah yang terpisah secara etnik anti thesis terhadap tujuan pendidikan multikultural mempertahankan dan memperluas solidaritas kelompok akan menghambat sosialisasi ke dalam kebudayaan baru. Pendidikan bagi pluralism budaya dan pendidikan multikultural tidak dapat disamakan secara logis. Keempat, Pendidikan multikultural meningkatkan kompetensi dalam beberapa kebudayaan. Kebudayaan mana yang akan diadopsi, itu ditentukan oleh situasi dan kondisi secara proporsional. Kelima, kemungkinan bahwa pendidikan (formal, maupun non formal) meningkatkan kesadaran tentang kompetensi dalam kebudayaan. Kesadaran akan seperti ini akan menjauhkan kita konsep-konsep tri budaya atau dikotomi antara pribumi dan non pribumi. Pendidikan karakter yang di integrasikan dalam pembelajaran pendidikan kultural dapat memberikan pengalaman yang bermakna bagi murid murid karena mereka memahami, menginternalisasi, dan mengaktualisasikannya melalui proses pembelajaran. Dengan demikian nilai nilai tersebut dapat terserap secara alami lewat kegiatan sehari hari. Apabila nilai nilai tersebut juga dikembangkan melalui kultur sekolah maka kemungkinan besar untuk membentuk karakter lebih efektif. Salah satu tujuan belajar pendidikan multikultural ialah untuk mempelajari keberagaman budaya Indonesia sehingga siswa 
memahami dan menghormati perbedaan suku dan budaya Indonesia.

\section{Konsep Dasar Pendidikan Multikultural.}

Konsep pendidikan multikultural menjadi komitmen global sejalan dengan rekomendasi UNESCO, Oktober 1994 di Jenewa. Rekomendasi UNESCO tersebut memuat empat seruan: (a) pendidikan seyogyanya mengembangkan kesadaran untuk jenis kelamin, ras, etnik dan kultur; (b) pendidikan seyogyanya mendorong konvergensi gagasan yang memperkokoh perdamaian, persaudaraan, dan solidaritas dalam masyarakat; (c) pendidikan seyogyanya membangun kesadaran untuk menyelesaikan konflik secara damai; dan (d) pendidikan seyogyanya meningkatkan pengembangan kualitas toleransi dan kemauan untuk berbagi secara mendalam.

Menurut H.A.R. Tilaar (2002), pendidikan multikultural merupakan suatu wacana lintas batas. Dalam pendidikan multikultural, terkait masalah-masalah keadilan social (social justice), demokrasi, dan hak asasi manusia. Tidak mengherankan apabila pendidikan multikultural berkaitan dengan isu-isu politik, sosial, kultural, moral, edukasional dan agama. Tanpa kajian bidang-bidang ini maka sulit untuk diperoleh suatu pengertian mengenai pendidikan multikultural. Para pakar pendidikan mengidentifikasikan tiga lapis diskursus yang berkaitan dalam pendidikan multikultural: (1) Masalah kebudayaan. Dalam hal ini terkait masalahmasalah mengenai identitas budaya suatu kelompok masyarakat atau suku. Bagaimanakah hubungan antara kebudayaan dengan kekuasaan dalam masyarakat sehubungan dengan konsep kesetaraan di masyarakat, (2) Kebiasaankebiasaan. Tradisi, dan pola-pola kelakuan yang hidup di dalam suatu masyarakat, (3) Kegiatan atau kemajuan tertentu (achievement) dari kelompok-kelompok dalam masyarakat yang merupakan identitas yang melekat pada kelompok di masyarakat yang merupakan identitas yang melekat pada kelompok tersebut.

Menurut Choirul Mahfud (2009) pada dasarnya, model-model pembelajaran sebelumnya yang berkaitan dengan kebangsaan memang sudah ada. Namun, hal itu masih kurang memadai sebagai sarana pendidikan guna menghargai perbedaan masing-masing suku, budaya, etnis. Hal itu terlihat dengan munculnya konflik yang kerap terjadi pada realitas kehidupan berbangsa dan bernegara saat ini. Hal itu menunjukkan bahwa pemahaman toleransi masih amat kurang.

Menurut Stephen Hill (dalam Choirul : 2009), paling tidak ada tiga hal penting dalam pendidikan multikultural di Indonesia, yaitu: pertama, pendidikan multikultural berfungsi sebagai sarana alternatif pemecahan konflik; kedua, dengan pendidikan multikultural, siswa tidak akan tercerabut dari akar budayanya; ketiga, pendidikan multikultural relevan di alam demokrasi seperti saat ini.

\section{E. Implikasi Pendidikan Multikultural}

Menurut Parekh (dalam Choirul : 2009), Implikasinya terhadap pengembangan Pendidikan Multikultural adalah pemasukan bahan ajar yang berisi ide dari berbagai kelompok budaya. Diperlukan adanya pendidikan yang leluasa untuk mengeksplorasi perspektif dan budaya orang lain. Dengan mengekplorasi itu akan diperoleh inspirasi sehingga membuat anak menjadi sensitif terhadap pluralitas cara hidup, cara yang berbeda dalam menganalisa pengalaman dan ide, dan cara melihat berbagai temuan sejarah yang ada di seluruh dunia. Pendidikan memang mengajarkan nilai-nilai budayanya sendiri namun selain itu juga perspektif dan budaya orang lain di wilayah lain di seluruh dunia. Hal ini dapat membuat siswa "melek budaya" (cultural literacy) yang mampu melihat berbagai sudut pandang budaya yang pernah hidup di berbagai belahan dunia. Dahulu orang Persia (sekarang Iran) menganggap bahwa status sosial orang yang meninggal dapat diukur dari jumlah orang yang menangisi kepergian orang yang meninggal. Bandingkan dengan kondisi sekarang, kita bisa juga mengukur penghormatan masyarakat terhadap seseorang yang meninggal dari jumlah orang yang datang melayat. Ada unsur persamaan, bahwa seseorang yang terpandang, dihormati dan disukai akan diukur dari kuantitas dan kualitas dari orang yang datang ikut berbela sungkawa. Kuantitas diukur dari jumlah orang yang mengantarkan jenasah, dan kualitas diukur dari tingkat kesedihan orang-orang yang ditinggalkan dan merasa ditinggalkan.

Menurut Babtiste (dalam Choirul : 2009), Perlu adanya pelembagaan filsafat pluralisme budaya dalam sistem pendidikan yang dilandasi prinsip persamaan, saling menghormati, penerimaan dan pemahaman, dan komitmen moral 
demi keadilan sosial . Pendidikan Multikultural selalu dilandasi prinsip persamaan dan keadilan sosial. Implikasinya, kurikulum perlu direformasi sehingga benar-benar mencerminkan penghormatan atas pluralitas budaya.

Menurut A. Effendi Sanusi (2009) dalam artikelnya yang berjudul Pendidikan Multikultural dan Implikasinya mengatakan bahwa Pendidikan multikultural sebagai wacana baru di Indonesia dapat diimplementasikan tidak hanya melalui pendidikan formal, tetapi juga dapat dimplementasikan melalui pendidikan nonformal. Dalam pendidikan formal, pendidikan multikultural tidak harus dirancang khusus sebagai muatan substansi tersendiri, tetapi dapat diintegrasikan dalam kurikulum yang sudah ada melalui bahan ajar atau model pembelajaran. Di Perguruan tinggi misalnya, dari segi substansi, pendidikan multikultural dapat diintegrasikan misalnya melalui mata kuliah umum, seperti kewarganegaraan, agama, dan bahasa. Pada tingkat SD, SLTP, atau sekolah menengah, pendidikan multikultural dapat diintegrasikan dalam bahan ajar seperti agama, sosiologi, dan antropologi, dan dapat melalui model pembelajaran, seperti diskusi kelompok atau kegiatan ekstrakurikuler. Dalam pendidikan nonformal, pendidikan multikultural dapat disosialisasikan melalui pelatihan-pelatihan dengan model pembelajaran yang responsif multikultural dengan mengedepankan penghormatan terhadap perbedaan, baik ras, suku, maupun agama antaranggota masyarakat.

Ide pendidikan multikultural memberi spirit bagi lembaga pendidikan nasional untuk mau menanamkan sikap kepada peserta didik untuk menghargai orang, budaya, agama dan keyakinan lain, dengan harapan akan membantu siswa mengerti menerima dan menghargai orang lain yang berbeda suku, budaya, nilai dan kepribadian.

Pendidikan multikultural sekurang-kurangnya mempunyai lima tujuan. Pertama, meningkatkan pemahaman diri dan konsep diri secara baik. Kedua, meningkatkan kepekaan dalam memahami orang lain, termasuk terhadap berbagai kelompok budaya di Negara sendiri dan Negara lain. Ketiga, meningkatkan kemampuan untuk merasakan dan memahami kemajemukan, interpretasi kebangsaan dan budaya yang kadang-kadang bertentangan menyangkut sebuah peristiwa, nilai dan perilaku. Keempat, membuka pikiran ketika merespon isu. Kelima, memahami latar belakang munculya pandangan klis atau kuno, menjauhi pandangan stereotipe dan mau menghargai semua orang.

Dalam implementasinya paradigma pendidikan multikultural dituntut untuk berpegang pada prinsip- prinsip berikut ini: (1) Pendidikan multikultural harus menawarkan beragam kurikulum yang merepresentasikan pandangan dan perspektif banyak orang, (2) Pendidikan multikultural harus didasarkan pada asumsi bahwa tidak ada penafsiran tunggal terhadap kebenaran sejarah, (3) Kurikulum dicapai ssuai dengan penekanan analisis komparatif dengan sudut pandang kebudayaan yang berbeda- beda, dan (4) Pendidikan multikultural harus mendukung prinsip-prinsip pokok dalam memberantas pandangan klis tentang ras, budaya dan agama.

Agar pendidikan lebih multikultural, maka pendidikan dan pengajaran harus memperkokoh pluralisme dan menentang adanya rasisme, diskriminasi gender dan bentuk- bentuk lain dari intoleransi dan dominasi sosial. Pada konteks ini kita harus lakukan transformasi kurikulum, model pembelajaran, suasana sekolah, kegiatan ekstrakurikuler dan peran dosen sebagai multikultural.

Prinsip- prinsip penting dalam penerapan pendidikan multikultural adalah kurikulum berdasarkan sejarah dan berpusat pada keragaman, berorientasi pada perbaikan, pengajaran mengarah pada keragaman, kurikulum tergantung pada konteks, bersifat menyerap keragaman dan dapat diterapkan secara luas, bersifat komprehensif serta mencakup semua level pendidikan.

Selain itu isi, pendekatan, dan evaluasi kurikulum harus menghargai perbedaan dan tidak diskriminatif. Paradigma multikultural perlu mewarnai model pembelajaran yang diterapkan dalam kelas. Langkah- langkah untuk mengembangkan model pembelajaran multikultural sebagai berikut: (1) Dosen mereduksi atau mengikis sikap negatif yang mungkin mereka miliki terhadap pluralisme, (2) Seorang pendidik atau anak didik melakukan analisis agar akrab dengan masyarakat, (3) Seorang pendidik dan anak didik memilih materi yang relevan dan menarik, dan (4) Seorang pendidik dan anak didik, bersama- sama menyelediki persoalan materi yang dipilih.

Pada akhirnya ide dari pendidikan multikultural bisa diterapkan atau tidak tergantung pada 
usaha kita bersama. Pendidikan multikultural sebaiknya dimasukkan dalam kurikulum sebagai mata pelajaran ekstrakurikuler atau menjadi bagian dari kurikulum sekolah khususnya daerah konflik atau daerah bekas konflik, dan semua daerah pada umumnya.

\section{F. Implementasi Pendidikan Multikultural Melalui Pendekatan Nilai Luhur Pancasila dan Budaya di STKIP PGRI Sumenep}

Pendidikan multikultural di STKIP PGRI SUMENEP sudah dapat dikatakan sangat baik, hal ini dapat dilihat dari beberapa aspek yaitu pertama tentang penanaman nilai-nilai multikultural di wujudkan dalam pendidikan formal (Perguruan tinggi) yaitu melalui kegiatan pembelajaran di dalam kelas. Pendidikan multikultural memang erat kaitannya dengan mata pelajaran IPS dan ilmu sosial budaya dasar (ISBD) akan tetapi implementasi pendidikan multikultural juga diterapkan dan disisipkan disemua mata pelajaran mengingat pentingnya pengimpelementasian pendidikan multikultural di STKIP PGRI SUMENEP. Selain melalui pendidikan formal (Perguruan tinggi) pendidikan multikultural juga diwujudkan melalu pendidikan non formal seperti, yaitu melalui kegiatan beribadah dan forum-forum diskusi yang dilakukan mahasiswa setiap harinya. Selain itu juga pendidikan multikultural juga diwujudkan dalam bentuk kegiatan intra kulikurel dan ekstrakulikuler mahasiswa dengan mahasiswa yang lain diluar jam Perguruan tinggi.

Kedua, menciptakan suasana lingkungan Perguruan tinggi yang multikultur sesuai ciri khas bangsa Indonesia yakni ketimuran. Suasana lingkungan Perguruan tinggi yang multikultur ini dapat dilihat dari keragaman mahasiswanya dan suasana Perguruan tinggi sendiri. Tujuan menciptakan suasana Perguruan tinggi yang multikultur disini adalah untuk membuat mahasiswa terbiasa dengan adanya perbedaan di lingkungan Perguruan tinggi mereka sehingga mereka dapat hidup rukun dan harmonis dengan adanya perbedaan itu serta

Adapun faktor pendukungnya yaitu antara lain kerjasama yang solid dan baik antar semua komponen Perguruan tinggi, lingkungan Perguruan tinggi yang multikultur, fasilitas berupa intra dan ekstrakulikurel yang memadai dan keluasan bagi mahasiswa untuk mengembangkan potensi. Selain itu faktor penghambatnya yaitu adaptasi mahasiswa, lokasi Perguruan tinggi dan dana yang berasal dari yayasan.

Pendidikan multikultural adalah pendidikan yang menghargai keberagaman dan mencakup perspektif dari berbagai kelompok budaya. Pengikutnya yakin bahwa anak-anak kulit berwarna harus diberdayakan dan bahwa pendidikan multikultural menguntungkan semua mahasiswa. Satu tujuan penting dari pendidikan multikultural adalah kesempatan pendidikan yang sama untuk semua mahasiswa, termasuk menghapuskan perbedaan prestasi akademis antara mahasiswa kelompok mayoritas dan mahasiswa dari kelompok minoritas.

Mengacu pada penjelesan apa itu pendidikan multikultural melalui pendekatan nilai luhur pancasila dan budaya seperti keterangan diatas jika dikaitkan dengan penjelasan dari ketua Perguruan tinggi dan urusan kurikulum dapat disimpulkan bahwa STKIP PGRI SUMENEP memang memandang bahwa Implementasi pendidikan multikultural melalui pendekatan nilai luhur pancasila dan budaya diperlukan dan dianggap penting di Perguruan tinggi tersebut untuk membangun mahasiswa yang berkarakter. Hal itu dapat dilihat dari perlakuan mahasiswa terhadap mahasiswa lain dan mereka sangat mengahargai.

Sebagaimana yang telah diungkapkan Dalam bukunya Multikultural Education: A Teacher Guide to Linking Context, Process, Content, Hilda Hernandez (dalam Choirul : 2009) yaitu, pendidikan multukultural sebagai perspektif yang mengakui realitas politik, sosial, dan ekonomi yang dialami oleh masingmasing individu dalam pertemuan manusia yang kompleks dan secara kultur, dan merefleksikan pentingnya budaya, ras, seksualitas dan gender, etnisitas, agama, status sosial, ekonomi, dan pengecualianpengecualian dalam proses pendidikan. Atau dengan kata lain, bahwa ruang pendidikan sebagai media transformasi ilmu pengetahuan (transfer of knowledge) hendaknya mampu memberikan nilai-nilai multikulturalisme dengan cara saling menghargai dan menghormati atas realitas yang beragam (plural), baik latar belakang maupun basis sosio budaya yang melingkupinya. 
Pendidikan multikultural merupakan salah satu model pembelajaran pendidikan yang dikaitkan pada sebuah keragaman yang ada, entah itu bicara tentang keagamaan, ras, bahasa, etnis, suku, budaya dan lain sebagainya. Hal ini dilakukan karena banyak kita jumpai Perguruan tinggi-Perguruan tinggi yang baik itu di dalam kelas maupun di luar kelas mahasiswa sangat beragam. Mengingat negara kita memang negara yang sangat kaya akan keberagaman, jadi tidak heran jika menjumpai hal semacam itu.

Begitu pula yang ada di STKIP PGRI SUMENEP, mahasiswa yang menimba ilmu di Perguruan tinggi tersebut memiliki latar belakang keragaman yang luar biasa. Yang menjadikan Perguruan tinggi ini berbeda dan menarik dengan Perguruan tinggi yang ada di Sumenep lainnya yaitu keberadaan intra dan ekstrakulikurel yang berfungsi sebagai tempat berkarya bagi mahasiswa yang selalu diberikan fasilatas yang memadai dan selalu diberikan kebebasan untuk selalu membuat kegiatan/acara di kampus maupun diluar kampus, sehingga kampus pada siang dan malam harinya tidak tampak sepi. Dalam satu intra dan ekstrakulikurel terdapat mahasiswa yang beragam dari segi bahasa, etnis, suku serta agama. Mahasiswa tersebut dapat hidup rukun dan berdampingan dengan guyub dan rukun. Tanpa mengesampingkan sikap toleransi, saling menghormati dan peduli sesama timbul akibat intensitas pertemuan dan komunikasi mereka terjalin begitu banyak, mereka bisa bertemu di lingkungan formal kelas dan di luar kelas baik itu jam ekstrakulikuler.

STKIP PGRI Sumenep memiliki suasana ataupun nuansa yang sangat multikultur dan sanga menjunjung adat ketimuran. Hal ini tampak dari sikap dan sopan santun mahasiswa yang bergaul dan peduli terhadap sesama tanpa memandang dari mana mahasiswa tersebut berasal. Suasana lingkungan yang multikultur tidak hanya datang dari segi mahasiswanya yang berasal dari daerah di seluruh penjuru Indonesia melainkan dengan suasana Perguruan tinggi yang rindang dan asri juga membuat mahasiswa merasa nyaman dan tidak terlalu lama dalam beradaptasi khususnya mahasiswa dari dari kepulauan yang terbiasa hidup dengan alam.

STKIP PGRI SUMENEP ini memang Perguruan tinggi dibawah naungan Yayasan. Sejak awal berdirinya STKIP PGRI SUMENEP telah menanamkan pendidikan multikultural (nilai-nilai multikulural) kepada mahasiswanya baik dilingkungan Perguruan tinggi, maupun diluar Perguruan tinggi. Dari proses penanaman pendidikan multkultural (nilai-nilai multikultural) yang ditanamkan sejak mahasiswa awal masuk Perguruan tinggi dan intensitas pertemuan yang banyak menjadikan mahasiswa STKIP PGRI SUMENEP ini memiliki sikap toleran, serta saling menghargai antar sesama. Selain itu mahasiswanya juga sangat menjunjung adat ketimuran sesuai dengan karakter bangsa Indonesia sendiri yaitu yang bersosialisasi, ramah dan sopan. Hal ini membuat setiap orang yang berada dilingkungan STKIP PGRI Sumenep merasa nyaman karena semuanya mudah berbaur.

Penerapan pendidikan multikultural di STKIP PGRI SUMENEP ini dilaksanakan baik melalui pendidikan formal (di Perguruan tinggi), pendidikan non formal (Ekskul) dan juga diluar lingkungan Perguruan tinggi. Dari hasil observasi tersebut didapat keterangan bahwa penerapan pendidikan multikultural dapat dilakukan dimana saja. Tidak harus dalam lingkup Perguruan tinggi, di luar Perguruan tinggi pun jika bertemu dengan dosen atau jika sedang bermain dan mengerjakan tugas dengan teman-temannya disitu pendidikan multikultural bisa masuk.

Penyelenggaraan pendidikan multikultural di STKIP PGRI Sumnep menuntut adanya penyesuaian baik dari segi kurikulum, sarana dan prasarana pendidikan, maupun sistem pembelajaran yang disesuaikan dengan Lingkungan STKIP PGRI Sumnep Namun, pendidikan multikultural tidak harus berdiri sendiri, tetapi dapat terintegrasi dalam mata pelajaran dan proses pendidikan yang ada di sekolah termasuk keteladanan para dosen dan intansi yang terkai di STKIP PGRI Sumnep. Seperti ditulis Azyumardi Azra (2003), bahwa pengimplementasian pendidikan multikultural dapat diterapkan di sekolah atau Perguruan tinggi dan masyarakat secara keseluruhan dengan cara memasukkan materi yang memiliki nilai multikultural.

Bentuk yang paling sederhana adalah menambahkan aspek multikultural ke dalam kurikulumnya. Oleh karena itu, pendidikan multikultural haruslah mencakup hal yang berkaitan dengan toleransi, perbedaan etnokultural dan agama, budaya, bahaya diskriminasi, penyelesaian konflik dan mediasi, HAM, demokrasi dan pluralitas, kemanusiaan uni- 
versal, dan subjek-subjek lain yang relevan mengantarkan terbentuknya masyarakat madani yang cinta perdamaian serta menghargai perbedaan. Isi dari pendidikan multikultural harus diimplementasikan berupa tindakan-tindakan, baik di STKIP PGRI Sumnep maupun di masyarakat.

STKIP PGRI Sumenep, dalam memberikan pendidikan multikultural tidak hanya diberikan lewat teori, atau dengan menambahkan ke dalam kurikulum yang sudah ada, tetapi juga melalui praktik mengajar seperti disisipkan pada materi yang membahas masalah keberagaman, seperti IPS, ISBD, Pendidikan Agama dan Pendidikan Kewarganegaraan. Pendidikan multikultural melalui pendidikan Kewarganegaraan dan pendidikan Agama serta pendidikan lainnya, harus dilakukan secara komprehensif. Dimulai dari desain perencanaan dan kurikulum melalui proses penyisipan, pengayaan dan atau penguatan terhadap berbagai kompetensi yang telah ada, mendesain proses-proses pembelajaran yang bisa mengembangkan sikap siswa untuk bisa menghormati hak-hak orang lain, tanpa membedakan latar belakang ras, agama, bahasa dan budaya, dan tanpa membedakan mayoritas dan minoritas. Pencapaian pendidikan multikultur harus dapat diukur melalui evaluasi yang relevan, apakah melalui instrumen tes, nontes atau melalui proses pengamatan longitudinal dengan menggunakan portofolio siswa.

Dari aspek metode, strategi dan manajemen pembelajaran merupakan aspek penting dalam penerapan pendidikan multikultural, karena manajemen serta proses-proses pembelajaran merupakan praktik dan prosedur yang memungkinkan dosen mengajar dan siswa belajar. Dalam proses pembelajaran di STKIP PGRI Sumenep, banyak sekali materi serta proses pembelajaran yang memuat tentang nilai-nilai multikultural dan saling menghargai antara yang satu dengan yang lainnya, baik oleh mahasiswa ataupun dosen serta komponen lainnya.

Berikut beberapa bentuk metode serta strategi di STKIP PGRI Sumnep Maguwoharjo dalam proses pembelajaran yang mengandung nilai-nilai multikultural:

\section{a) Cooperatif Learning}

Suatu strategi belajar mengajar yang menekankan pada sikap atau perilku bersama (team working) dalam bekerja atau membantu di antara semua dalam struktur kerjasama yang teratur dalam kelompok yang terdiri dari dua orang atau lebih. Dalam kelompok ini, mahasiswa tidak dibedakan menurut kemampuan, karena disinilah mahasiswa dilatih untuk peka terhadap perbedaan dan sikap saling menghargai perbedaan.

\section{b) Approach}

Proses pembelajaran yang di dorong oleh pertanyaan mahasiswa yang menggerakkan pemahaman awal mahasiswa ke tingkat yang lebih tinggi atau dalam. Metode ini merupakan proses pembelajaran agar mahasiswa mampu berfikir kritis dalam melakukan penelitian sehingga memiliki pembelajaran yang reflektif.

\section{c) Active Learning}

Pembelajaran aktif adalah segala bentuk pembelajaran yang memungkinkan mahasiswa berperan secara aktif dalam proses pembelajaran itu sendiri baik dalam bentuk interaksi antar mahasiswa maupun mahasiswa dengan pengajar dalam proses pembelajaran tersebut.

\section{d) Teaching in Differentiation}

Sebuah strategi pembelajaran yang merespon kebutuhan dan kemampuan mahasiswa terutama untuk mahasiswa yang berkebutuhan khusus (ABK) jika ada, untuk memberikan dan memfasilitasi proses pembelajaran terbaik yang disesuaikan dengan kondisi dan potensi anak didik.

e) IDU (Interdiciplinary Unit Programme)

Sebuah program interdisipliner, yakni program yang mengembangkan pendekatan cara belajar dengan membangun link atau hubungan antar mata kuliah dan matakuliah yang lain.

Proses pembelajaran dalam kegiatan belajar mengajar selalu memperhatikan individu peserta didik serta menghormati harkat, martabat, dan kebebasan berfikir dalam mengeluakan pendapat, sehingga bagi pesera didik belajar merupakan hal yang menyenangkan dan dapa ditempuh oleh siapapun tanpa memandang anak tersebut berasal dari mana, ras apa, suku dan lain sebagainya sehingga belajar menjadi menyenangkan dan mendorong kepribadiannya berkembang secara optimal.

Pendidikan multikultural di STKIP PGRI Sumenep, selain diimplementasikan ke dalam kurikulum, juga pengimplementasiannya dilakukan di luar sekolah. Pendidikan tidak hanya bersifat akademik saja, tetapi ada pula yang bersifat non akademik. Dalam lembaga pendidikan, pendidikan yang bersifat non 
akademik biasanya dimasukkan dalam ekstrakurikuler.

Kegiatan-kegiatan kemahasiswaan merupakan suatu wadah atau kegiatan-kegiatan yang positif agar mahasiswa dapat menyalurkan bakat, minat ataupun kreatifitasnya pada kegiatan-kegiatan non akademik. Kegiatan ekstrakurikuler antara lain dalam bidang olah raga, seni, karya ilmiah, pecinta alam, ilmu pengetahuan ataupun keagamaan. Kegiatankegiatan kemahasiswaan diantaranya adalah kegiatan intrakurikuler dan ekstrakurikuler.

Kegiatan intrakurikuler dan ekstrakurikuler dapat menumbuhkan nilai-nilai kebersamaan, kerukunan hidup serta menghargai keberadaan perbedaan yang ada. Setiap siswa memperoleh hak yang sama untuk memilih kegiatan ekstrakurikuler yang diminati tanpa memandang asal dan latar belakangnya. Di setiap kegiatankegiatan yang mengarah pada kebiasaan multikultur dengan sikap dan perilaku yang toleran antar teman, kebersamaan, solidaritas dan bisa saling bekerja sama dengan baik.

Oleh sebab itu, nampaknya dari penjelasan itu penerapan pendidikan multikultural sudah sangat dipahami dan dianggap penting oleh semua warga STKIP PGRI Sumenep. Komunikasi antara dosen dengan dosen, dosen dengan mahasiswa, maupun mahasiswa dengan mahasiswa STKIP PGRI Sumenep ini sangat bersifat kekeluargaan. Dalam berkomunikasi dengan mahasiswa, dosen tidak pernah memandang dan menyangkut pautkan ras, suku, budaya, bahasa maupun agama. Setiap bertemu dosen baik seagama maupun tidak mahasiswa selalu bertegur sapa dan bersalaman. Begitu juga antara mahasiswa dengan mahasiswa, baik seagama ataupun tidak mereka bergaul bersama, bermain bersama, makan bersama dan melakukan kegiatan lainnya secara bersama-sama.

Dari hasil observasi didapatkan keterangan bahwa upaya yang dilakukan pihak Perguruan tinggi terutama dosen untuk mengimplementasikan sebuah pendidikan multikultural seperti sikap saling toleransi, peduli dan saling menghormati yaitu dengan: (1) Selalu melakukan komunikasi dengan mahasiswa tanpa membedakan agama, ras, maupun suku bangsa, (2) Mendukung perayaan keagamaan yang melibatkan mahasiswa yang berbeda agama sebagai penitia, dan (3) Dosen sebagai panutan dan teladan, harus memberikan contoh yang baik karena semua mahasiswa pasti meniru apa yang dilakukan oleh dosen. Karena bgaimanaupun juga dosen merupakan figur orang tua dalam lingkup Perguruan tinggi. Dosen adalah petugas lapangan dalam pendidikan yang selalu berhubungan secara langsung dengan mahasiswa sebagai obyek pokok dalam pendidikan.

Moh Yamin dan Vivi Aulia (2011) mengatakan bahwa sebuah semangat toleransi yang ditanamkan dalam hati sanubari setiap masyarakat dan dipraktikkan dalam kehidupan sosial merupakan sebuah modal sangat kuat bagi mengembangkan sebuah peradaban hidup yang berbasiskan pada kedamaian dan perdamaian hidup.

\section{Simpulan.}

Pendidikan multikultural merupakan proses penanaman nilai-nilai dan cara hidup menghormati, tulus, dan toleran terhadap keragaman budaya yang hidup di tengah-tengah masyarakat plural. Dengan pendidikan multikultural melui pendekatan nilai luhur pancasila dan budaya diharapkan membangun karakter mahasiwa dalam menghadapi arus globalisasi dan konflik sosial.

Pendidikan multikultural tidak harus berdiri sendiri, tetapi dapat terintegrasi dalam matakuliah dan proses pendidikan yang ada di perguruan tinggi termasuk keteladanan para dosen dan pihak terkait di perguruan tinggi tersebut. Isi dari pendidikan multikultural harus diimplementasikan berupa tindakan-tindakan, baik di perguruan tinggi maupun di masyarakat. Salah satu upaya untuk membangun karakter, kesadaran dan pemahaman generasi yang akan datang adalah dengan penerapan pendidikan multikultural melalui pendekatan nilai luhur pancasila dan budaya. Hal ini dikarenakan pendidikan multikultural adalah proses penanaman cara karakter, hidup menghormati, tulus, dan toleran terhadap keanekaragaman budaya yang hidup di tengah-tengah masyarakat plural.

\section{DAFTAR PUSTAKA}

[1] Adi W. Gunawan,. 2005. Hypnosis - The Art of Subconscious Communication.Jakarta: PT Gramedia Pustaka Utama.

[2] Ali, Muhamad. 2003. Teologi PluralisMultikultural: Menghargai Kemajemukan Menjalin Kebersamaan. Jakarta. Penerbit Buku Kompas 
[3] Ariesandi Setyono,. 2006. Hypnoparenting: Menjadi Orangtua Efektif dengan Hipnosis. Jakarta: PT. Gramedia Pustaka Utama.

[4] Azra, Azyumardi. 2003. Pendidikan Multikultural; Membangun Kembali Indonesia Bhineka Tunggal Ika, dalam Tsaqafah, Vol. I, No. 2.

[5] Banks, J.A. 1993. "Multikultural Educatian: Historical Development, Dimentions and Practrice” In Review of Research in Education, vol. 19, edited by L. Darling- Hammond. Washington, D.C.: American Educational Research Association.

[6] Bertens K. 1997. Etika. Jakarta: PT Gramedia Pustaka Utama.

[7] Efendi, Sanusi. 2009. Pendidikan Multikultural dan Implikasinya. Di http://multinalarisme.blogspot.co.id./2010/01/p endidikan-multikultural-dan.html, diakses pada $15 / 09 / 2016$

[8] H.A.R. Tilaar,. 2004. Multikulturalisme, Tantangan-Tantangan Global Masa Depan dalam Transformasi Pendidikan Nasional, Grasindo, Jakarta.

[9] .2002. Perubahan Sosial dan Pendidikan, Pengantar Pedagogik Tarnsformatif untuk Indonesia. Jakarta: Gramedia.

[10] Hurlock, Elizabeth B. 1978. Perkembangan anak Jilid 1 \& II. Jakarta : Erlangga.

[11] Joseph Murphy D.R.S. 2002. Rahasia Kekuatan Pikiran Bawah Sadar. Jakarta: SPEKTRUM.

[12] Liliweri, Alo. 2005. Prasangka dan Konflik: Komunikasi Lintas Budaya Masyarakat Multikultural. Yogyakarta. LKiS.

[13] Phillips, Sally. 1997. Opportunities and Responsibilities; Competence, Creativity, Collaboration, and Caring, dalam, John K Roth, 'Inspiring Teaching', Anker Publishing Company, USA.
[14] Sada, Clarry. 2004. Multicultural Education in Kalimantan Barat; an Overview, dalam Jurnal Multicultural Education in Indonesia and South East Asia, Edisi I.

[15] Madjid, Nurcholish,. 1995. Islam Agama Peradaban, Membangun Makna dan Relevansi Doktrin Islam dalam Sejarah, Paramadina, Jakarta.

[16] Mahfud, Choirul. 2009. Pendidikan Multikultural, Yogyakarta: Pustaka Pelajar.

[17] Muhaemin, El-Ma'hady. 2004. Multikulturalisme dan Pendidikan Multikultural: Sebuah Kajian Awal http://pendidikannetwork.

[18] Naim, Ngainun dan Achmad Sauqi,. 2008. Pendidikan Multikultural: Konsep dan Aplikasi. Yogyakarta: Ar-Ruzz Media.

[19] Nanih Mahendrawati dan Ahmad Syafei,. 2001. Pengembangan Masyarakat Islam: Dari Ideologi, Strategi sampai Tradisi. Bandung: Remaja Rosdakarya.

[20] N.K. Singh dan Mr. A.R. Agwan, Encyclopaedia of the Holy Qur'ân, (New Delhi: balaji Offset, 2000) Edisi I h. 175

[21] Savage, T.V.,\& Armstrong, D.G. 1996. Effective Teaching in Elementary Social Studies. Ohio: Prentice Hall.

[22] Skeel, D.J. 1995. Elementary Sosial Studies: Challenge for Tomarrow"s World. New York: Harcourt Brace College Publishers.

[23] Yamin, Moh dan Aulia, Vivi. 2011. Meretas Pendidikan Toleransi. Malang: Madani Media.

[24] Zuly Qodir, Pendidikan Multikultural Di Yogyakarta di http://edukasi.kompas.com. Pendidikan.Multikultul. di.Yogyakarta, diakses pada $15 / 09 / 2016$ 